\title{
STUDI KARAKTERISTIK SIFAT KUALITATIF DAN KUANTITATIF AYAM KAMPUNG DI KECAMATAN LASALIMU KABUPATEN BUTON
}

\author{
Amlia ${ }^{1}$, Muh. Amrullah Pagala ${ }^{2}$, dan Rahim Aka ${ }^{2}$ \\ ${ }^{1}$ Alumnus Fakultas Peternakan UHO \\ ${ }^{2}$ Dosen Fakultas Peternakan UHO \\ "e-mail : amroe74@gmail.com
}

\begin{abstract}
ABSTRAK
Penelitian ini bertujuan untuk mengetahui karakteristik sifat kualitatif dan kuantitatif ayam kampung di Kecamatan Lasalimu Kabupaten Buton. Bahan penelitian adalah ayam kampung jantan dan betina umur di atas 6 bulan sebanyak 200 ekor yang terdiri atas 100 ekor jantan dan 100 ekor betina yang diambil secara random sampling. Data sifat kualitatif dan kuantitatif ditabulasi dan dianalisis secara deskriptif. Hasil penelitian tentang sifat kualitatif ayam kampung jantan yaitu bentuk jengger adalah tunggal $44 \%$, rose $32 \%$, pea $17 \%$, dan walnut $7 \%$. Bulu tipe bulu liar $35 \%$, hitam, $19 \%$, putih $14 \%$, dan columbian $32 \%$, lurik $19 \%$, polos $81 \%$, emas $54 \%$, perak $32 \%$. Warna kulit shank putih/kuning $87 \%$, dan hitam $13 \%$. Warna paruh putih/kuning $71 \%$ dan hitam/abu-abu $29 \%$ sedangkan ayam kampung betina memiliki bentuk jengger pea $40 \%$, walnut $11 \%$, tunggal $19 \%$, dan rose $30 \%$. Warna bulu hitam $32 \%$, putih $13 \%$, tipe bulu liar $28 \%$, columbian $26 \%$, lurik $8 \%$, polos $92 \%$, emas $35 \%$, dan perak $20 \%$. Warna kulit shank putih/kuning $69 \%$, dan hitam $31 \%$. Warna paruh putih/kuning 66\% dan hitam/abu-abu 34\%. Sifat kuantitatif ayam kampung jantan yaitu bobot badan $1.753,10 \mathrm{~g}$, lingkar dada $41,51 \mathrm{~cm}$, lebar dada $6,01 \mathrm{~cm}$, panjang shank $11,57 \mathrm{~cm}$ dan panjang jari utama $6,31 \mathrm{~cm}$ sedangkan ayam kampung betina yaitu bobot badan $1.216,71 \mathrm{~g}$, lingkar dada $37,47 \mathrm{~cm}$, lebar dada $5,19 \mathrm{~cm}$, panjang shank $7,06 \mathrm{~cm}$ dan panjang jari utama $5,32 \mathrm{~cm}$.
\end{abstract}

Kata kunci: Sifat kualitatif dan kuantitatif, Ayam kampung, Kecamatan Lasalimu

\begin{abstract}
The purpose of this research is to determine native chicken qualitative and quantitative characterization in buton subdistrict of lasalimu regency. Samples of This reseachs using 200 native chicken which is 100 male and 100 female in mature period and sampling method using random sampling. Data analized by statistic descriptive. Results of research on the qualitative nature of the male chicken is a form of single comb is $44 \%$, rose $32 \%, 17 \%$ pea and walnut $7 \%$. Wild-type fur fur $35 \%$, black $19 \%$, white $14 \%$ and columbian $32 \%$, striated $19 \%$, plain $81 \%$, gold $54 \%$, silver $32 \%$. Shank skin color white/yellow $87 \%$, and $13 \%$ black. Beak color white/yellow $71 \%$ and black/gray $29 \%$. while the female has a chicken's comb shape pea $40 \%$, walnuts $11 \%$ single, $19 \%$, and rose $30 \%$. Black coat color $32 \%$, white $13 \%$, wild-type feathers $28 \%$, columbian $26 \%$, striated $8 \%$, plain $92 \%$, gold $35 \%$ and silver 20\%. Shank skin color white/yellow $69 \%$, and $31 \%$ black. Beak color white/yellow $66 \%$ and black/gray $34 \%$. A quantitative nature, namely male chicken $1.753,10 \mathrm{~g}$ body weight, chest circumference $41,51 \mathrm{~cm}$, chest width $6,01 \mathrm{~cm}$, length and long shank $11,57 \mathrm{~cm}$ primary finger $6,31 \mathrm{~cm}$ chicken while females are $1.216,71 \mathrm{~g}$ body weight, chest circumference $37,47 \mathrm{~cm}$, chest width $5,19 \mathrm{~cm}$, long shank $7,06 \mathrm{~cm}$ and main finger length. $5,32 \mathrm{~cm}$
\end{abstract}

Key words : Qualitative and Quantitative Native Chicken, Lasalimu District

\footnotetext{
${ }^{*}$ Corresponding author
} 


\section{PENDAHULUAN}

Ayam kampung merupakan salah satu sumber kekayaan genetik ternak lokal yang ada di Indonesia. Dibandingkan dengan unggas lain, ayam kampung termasuk salah satu ternak yang memiliki kelebihan, yaitu pemeliharaan ayam kampung mudah atau sederhana, biaya yang dikeluarkan murah dan mempunyai daya tahan tubuh yang tinggi terhadap penyakit. Disisi lain produktivitas ayam kampung sangat lambat. Lambatnya pertumbuhan ayam kampung disebabkan oleh beberapa faktor, salah satunya adalah faktor genetik, dan umumnya peternak belum menerapkan program pemuliaan secara baik. Salah satu cara meningkatkan produktivitas ayam kampung adalah dengan melakukan perbaikan mutu genetik baik dengan seleksi maupun perkawinan silang yang biasa disebut dengan program pemuliaan. Keragaman sifat genetik yang meliputi sifat kualitatif dan kuantitatif sangat di perlukan dalam melakukan program pemuliaan.

Populasi ayam kampung di Kabupaten Buton pada tahun 2013 tercatat sebanyak 209.285 ekor. Populasi ayam kampung hampir menyebar secara merata dengan penyebaran jumlah populasi yang berbeda-beda ditiap kecamatan.

Kecamatan Lasalimu merupakan daerah dengan populasi ayam kampung terbanyak yaitu 49.677 ekor. Kecamatan Lasalimu merupakan pemasok kebutuhan ayam kampung di Kota Baubau, Kabupaten Buton dan Kabupaten Wakatobi (BPS Sulawesi Tenggara, 2015).

Tujuan dari penelitian ini adalah untuk mengetahui karakteristik sifat kualitatif dan kuantitatif ayam kampung di Kecamatan Lasalimu Kabupaten Buton. Hasil penelitian ini diharapkan dapat memberikan informasi bagi mahasiswa dan petani peternak tentang karakteristik sifat kualitatif dan kuantitatif ayam kampung dan dapat digunakan untuk meningkatkan produktivitas ayam kampung.

\section{MATERI DAN METODE}

Bahan penelitian adalah ayam kampung jantan dan betina umur di atas 6 bulan sebanyak 200 ekor yang terdiri atas 100 ekor jantan dan 100 ekor betina yang dipelihara di Kecamatan Lasalimu Kabupaten Buton. Pengambilan data dilakukan dengan secara purposive sampling. Parameter yang diamati pada penelitian ini meliputi sifat kualitatif dan sifat kuantitatif.

Data sifat kualitatif yang terkumpul selanjutnya ditabulasi dan dihitung persentasenya secara proporsional, sedangkan untuk sifat kuantitatif dihitung nilai rataan, simpangan baku dan koefisien variasinya kemudian dianalisis secara deskriptif.

\section{HASIL DAN PEMBAHASAN}

\section{A. Kondisi Wilayah Penelitian}

Kecamatan Lasalimu memilki luas wilayah $327,29 \mathrm{~km}^{2}$ dan terdiri dari 15 desa/kelurahan. Penduduk di Kecamatan Lasalimu pada tahun 2014 tercatat sebesar 10.134 jiwa (BPS Sulawesi Tenggara, 2015). Kecamatan Lasalimu merupakan bagian dari Kabupaten Buton, dengan batas-batas wilayah sebagai berikut :

- Sebelah Utara berbatasan dengan Kabupaten Buton Utara.

- Sebelah Selatan berbatasan dengan Kecamatan Pasarwajo.

- Sebelah Barat berbatasan dengan Kecamatan Kapontori.

- Sebelah Timur berbatasan dengan Laut Banda.

Masyarakat di Kecamatan Lasalimu umumnya bekerja sebagai petani, namun mereka juga berternak sebagai pekerjaan sambilan. Menurut data statistik 2013 jumah ternak di Kecamatan Lasalimu adalah 52.612 ekor. Umumnya jenis ternak yang dipelihara oleh masyarakat di Kecamatan Lasalimu adalah ternak ruminansia (sapi dan kambing) dan ternak unggas (ayam kampung, broiler dan itik). Menurut data statistik 2013 populasi ayam 
buras merupakan populasi terbanyak dari semua jenis ternak yang ada di Kecamatan Lasalimu adalah 49.677 ekor.

\section{B. Sifat Kualitatif Ayam Kampung}

\section{Bentuk Jengger Ayam Kampung}

Tabel 1. Persentase Bentuk Jengger Ayam Kampung Berdasarkan Jenis Kelamin (\%)

\begin{tabular}{lccccc}
\hline \multirow{2}{*}{ Fenotipe } & \multirow{2}{*}{ Genotipe } & \multicolumn{4}{c}{ Jenis kelamin } \\
\cline { 3 - 6 } & & \multicolumn{2}{c}{ Jantan $\mathbf{N}=\mathbf{1 0 0}$} & \multicolumn{2}{c}{ Betina $\mathbf{N}=\mathbf{1 0 0}$} \\
\hline Pea & rrPP & 17 & $17 \%$ & 40 & $40 \%$ \\
Tunggal & rrpp & 44 & $44 \%$ & 19 & $19 \%$ \\
Walnut & RrPp & 7 & $7 \%$ & 11 & $11 \%$ \\
Rose & RRpp & 32 & $32 \%$ & 30 & $30 \%$ \\
\hline
\end{tabular}

Keterangan : $\mathrm{N}=$ Sampel

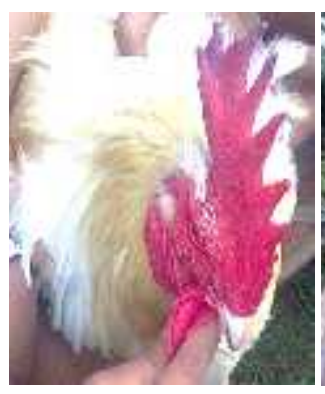

$\mathrm{a}$

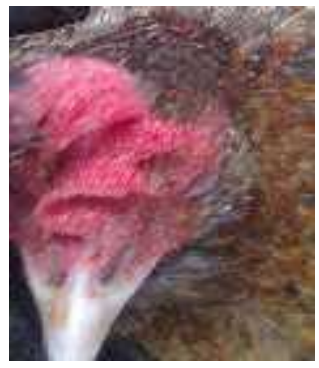

e

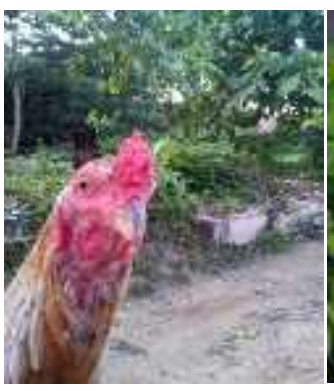

b

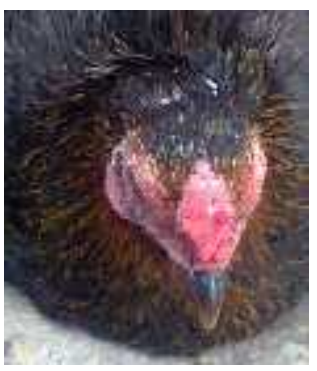

$\mathrm{f}$

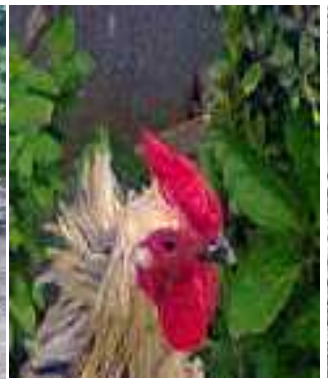

$\mathrm{c}$

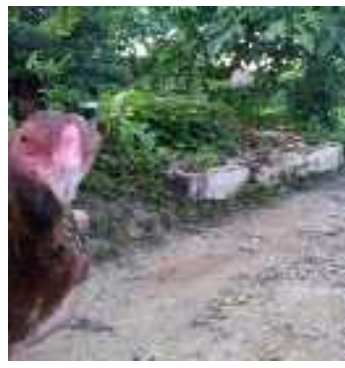

g

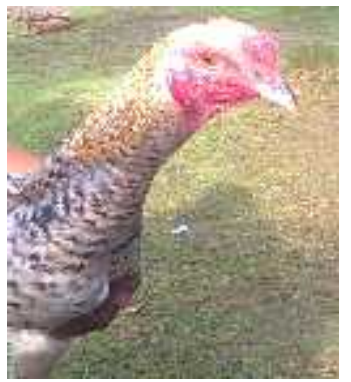

d

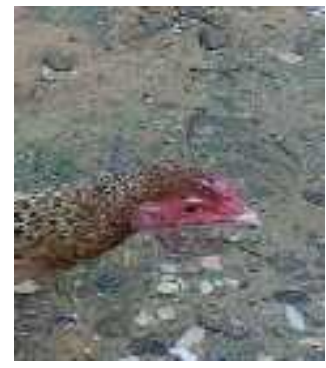

h

Gambar 1. Bentuk jengger ayam kampung di Kecamatan Lasalimu jantan: jengger (a) tunggal (b) rose, (c) pea dan (d) walnut betina: (e) tunggal (f) pea (g) rose dan (h) walnut

Jengger tunggal merupakan bentuk jengger yang dominan untuk ayam kampung jantan dan jengger pea pada ayam kampung betina di Kecamatan Lasalimu. Tingginya bentuk jengger tunggal pada ayam kampung jantan dikarenakan ayam kampung memiliki jarak genetik yang dekat dengan ayam hutan. Hal ini sesuai dengan pernyataan Subekti dan Arlina (2011) bahwa ayam kampung masih mempunyai jarak genetik yang dekat dengan ayam hutan merah yang ada di Indonesia. Lebih lanjut dikatakan bahwa perbedaan bentuk jengger ayam kampung jantan dan betina yang dominan disebabkan karena pengaruh gen pea kuat terhadap gen tunggal, dimana ayam kampung telah menerima aliran gen yang berasal dari bangsa ayam unggul 
yaitu ayam brahma yang memiliki bentuk jengger pea.

Sadarman dkk. (2013) bahwa bentuk jengger tunggal pada ternak jantan $(0,50)$ dan pada ternak betina lebih $(0,56)$ lebih tinggi frekuensi fenotipiknya jika dibandingkan dengan bentuk jengger pea, rose, dan walnut.

Tabel 2. Persentase Warna Bulu Ayam Kampung Berdasarkan Jenis Kelamin di Kecamatan Lasalimu (\%)

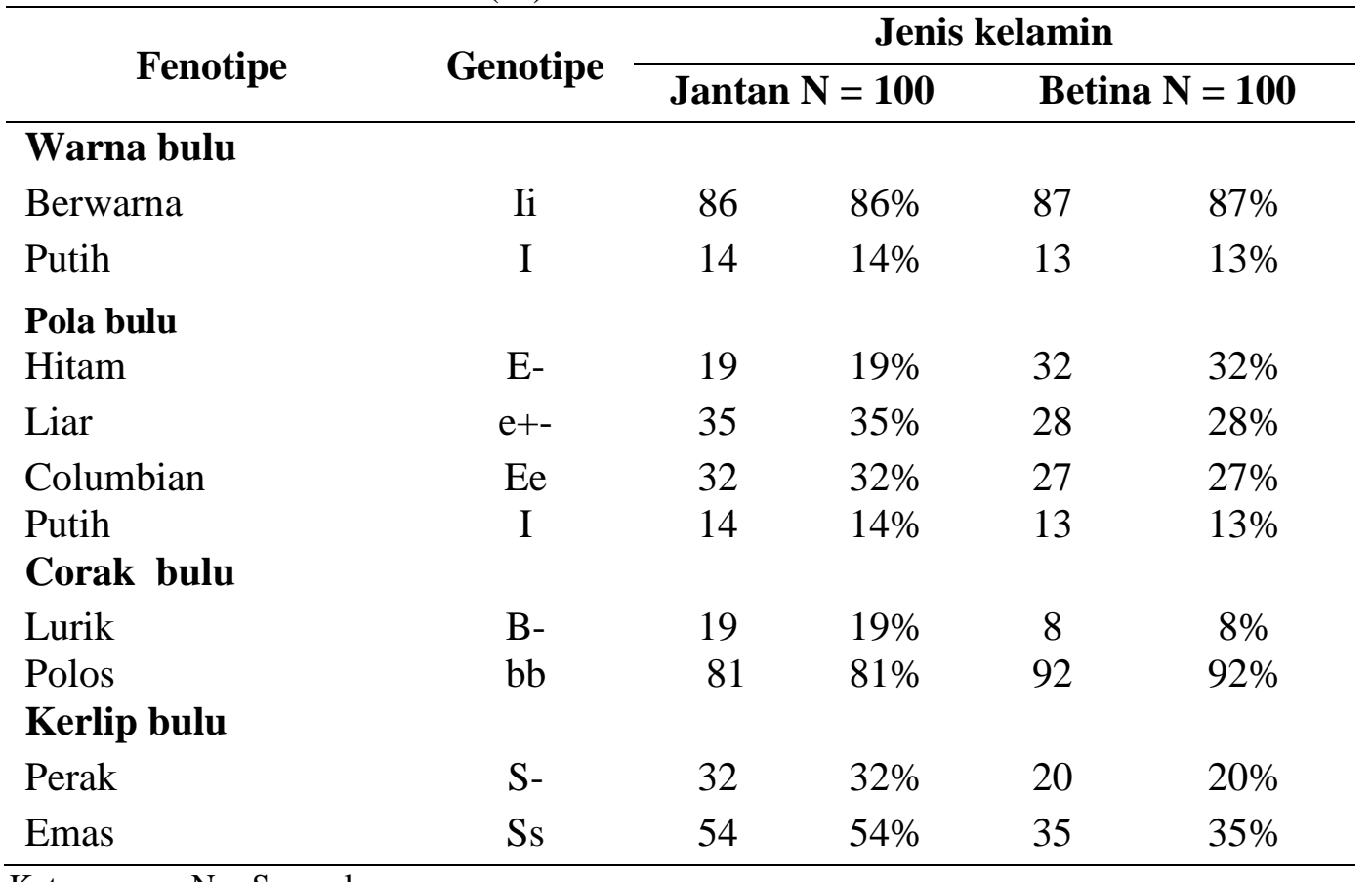

Keterangan : N = Sampel
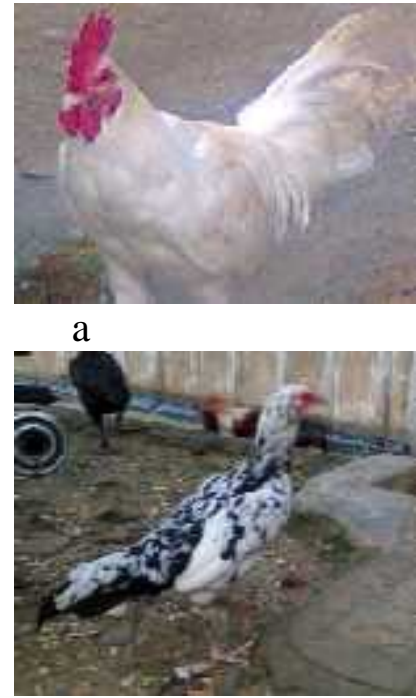

d

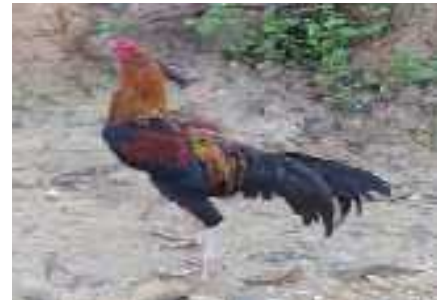

b

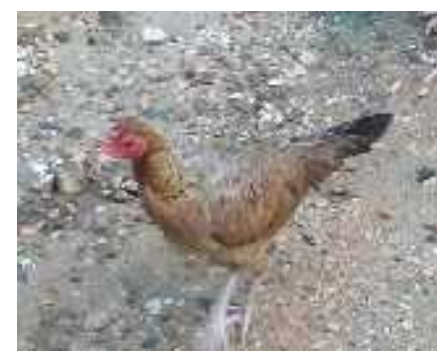

$\mathrm{e}$

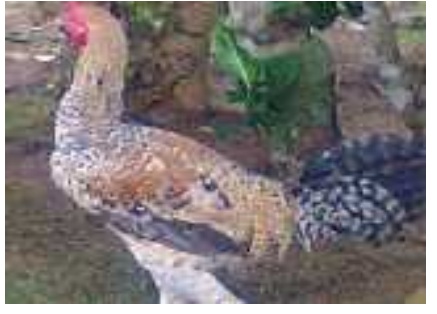

$\mathrm{c}$

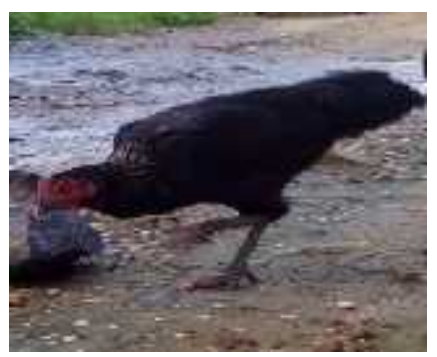

$\mathrm{f}$

Gambar 6. Warna bulu ayam kampung, Jantan: (a) Putih polos; (b) Columbian pola berwarna dengan kerlip bulu emas; (c) Columbian pola berwarna dengan kerlip bulu emas dan perak; (d) Betina: lurik; (e) Tipe columbian pola berwarna dengan kerlip bulu emas; (f) Hitam polos. 
Warna bulu ayam kampung dalam hasil penelitian ini masih sangat bervariasi. Hal ini menunjukan bahwa ayam kampung belum memiliki ciri-ciri khusus karena memiliki penampilan fenotipe yang masih beragam. Hal ini sesuai dengan pendapat Tantu (2007) bahwa ayam kampung didefinisikan sebagai ayam yang tidak mempunyai ciri-ciri khas, dengan kata lain penampilan fenotipenya masih sangat beragam. Sifat-sifat kualitatif seperti warna bulu sangat bervariasi, ada yang berwarna hitam (EE, $\mathrm{Ee}+, \mathrm{Ee})$, warna bulu tipe liar $(\mathrm{e}+\mathrm{e}+, \mathrm{e}+\mathrm{e})$, tipe columbian (ee), bulu putih (I-cc) serta warna lurik (B-, Bb) masih bercampur baur. Warna bulu ayam dipengaruhi oleh adanya pigmen melanoblast yang dibentuk saat awal embrio sekitar 8 jam inkubasi Scanes dkk. (2003).

Sadarman dkk. (2013) melaporkan bahwa warna bulu ayam kampung yang dipelihara di Desa Menaming sebagian besar berwarna (ii) dan hanya sebagian kecil yang memiliki bulu putih (I-) atau tidak berwarna. Pola warna bulu dengan frekuensi tertinggi pada jantan adalah pola warna liar yaitu 0,60 sedangkan pada ayam betina adalah pola warna hitam yaitu 0,56 . Corak bulu dengan frekuensi tertinggi baik jantan maupun betina adalah corak lurik pada ternak jantan 0,58 dan betina 0,54. Kerlip bulu dengan frekuensi tertinggi baik jantan maupun betina adalah kerlip bulu emas yaitu 0,66 untuk ternak jantan dan 0,62 untuk ternak betina.

\section{Warna Shank Ayam Kampung di Kecamatan Lasalimu}

Hasil pengamatan terhadap sifat kualitatif warna shank ayam kampung yang di pelihara di Kecamatan Lasalimu disajikan pada Tabel 3 dan Gambar 3.

Tabel 3. Persentase Warna Shank Ayam Kampung Berdasarkan Jenis Kelamin di Kecamatan Lasalimu (\%)

\begin{tabular}{lllrlr}
\hline \multirow{2}{*}{ Fenotipe } & \multirow{2}{*}{ Genotipe } & \multicolumn{4}{c}{ Jenis kelamin } \\
\cline { 3 - 6 } & & \multicolumn{2}{c}{ Jantan $\mathbf{N = 1 0 0}$} & \multicolumn{2}{c}{ Betina $\mathbf{~ = ~ 1 0 0 ~}$} \\
\hline Putih/ kuning & Id- & 87 & $87 \%$ & 69 & $69 \%$ \\
Hitam/abu-abu & Idid & 13 & $13 \%$ & 31 & $31 \%$ \\
\hline
\end{tabular}

Keterangan : $\mathrm{N}=$ Sampel

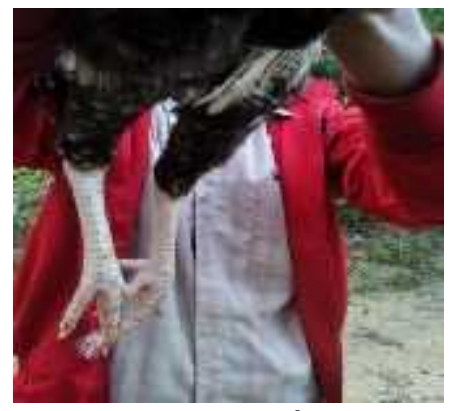

4. a

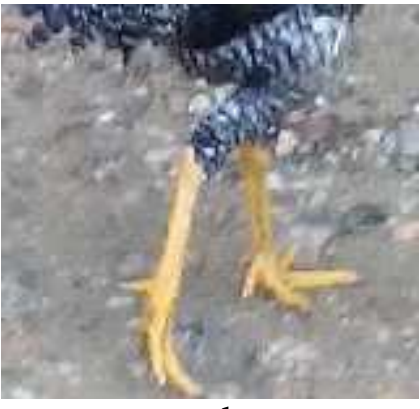

b

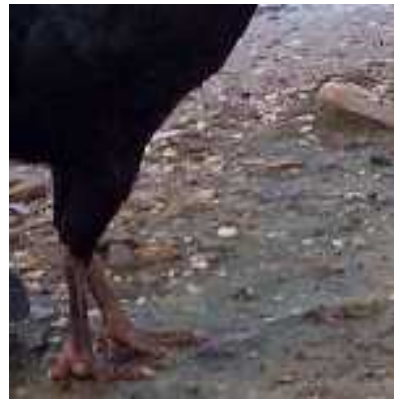

C

Gambar 3 . Warna shank ayam kampung: (a) Putih, (b) Kuning dan (c) Hitam .

Umumnya warna shank ayam kampung jantan dan betina di Kecamatan Lasalimu berwarna putih/kuning dan hitam/abu-abu. Warna shank putih/kuning merupakan warna shank yang dominan baik pada ternak jantan maupun pada ternak betina. Warna shank hitam/abu-abu pada ayam kampung disebabkan oleh tingginya kandungan melanin pada lapisan dermis sedangkan warna shank putih/kuning disebabkan oleh kurangnya kandungan melanin pada lapisan dermis (albino). Hal ini sesuai dengan pernyataan Sartika dkk. (2006) bahwa karakteristik 
warna cakar kuning atau putih (id) disebabkan oleh kurangnya kandungan melanin pada jaringan kulit (dermis). Kandungan melanin dalam lapisan kulit (dermis) dikontrol oleh gen resesif terkait kelamin (id) dalam keadaan homozigot atau heterozigot. Warna cakar hitam Id (inhibitor dari melanin dermis) bersifat dominan tidak lengkap terhadap id.

Subekti dan Arlina (2011) melaporkan warna kulit kaki/shank ayam kampung yang di pelihara di Kecamatan Sungai Pagu pada ternak jantan lebih dominan kuning/putih (74\%) dan pada ternak betina $(66 \%)$ sedangkan warna kulit kaki/shank hitam pada ternak jantan (26\%) dan pada ternak betina (34\%). Namun berbeda dengan hasil penelelitian Sartika dkk. (2008) yang menyatakan bahwa warna shank pada ayam kampung mayoritas berwarna hitam yaitu sebesar $72,21 \%$.

\section{Warna Paruh Ayam Kampung di}

\section{Kecamatan Lasalimu}

Hasil pengamatan terhadap sifat kualitatif warna paruh ayam kampung yang di pelihara di Kecamatan Lasalimu disajikan pada Tabel 4 dan Gambar 4.

Tabel 4. Persentase Warna Paruh Ayam Kampung Berdasarkan Jenis Kelamin di Kecamatan Lasalimu (\%)

\begin{tabular}{lllccc}
\hline \multirow{2}{*}{ Fenotipe } & \multirow{2}{*}{ Genotipe } & \multicolumn{4}{c}{ Jenis kelamin } \\
\cline { 3 - 6 } & & \multicolumn{2}{c}{ Jantan $\mathbf{N = 1 0 0}$} & \multicolumn{2}{c}{ Betina $\mathbf{~ = ~ 1 0 0 ~}$} \\
\hline Putih/ kuning & Id- & 71 & $71 \%$ & 66 & $66 \%$ \\
Hitam/abu-abu & Idid & 29 & $29 \%$ & 34 & $34 \%$
\end{tabular}

Keterangan : $\mathrm{N}=$ sampel

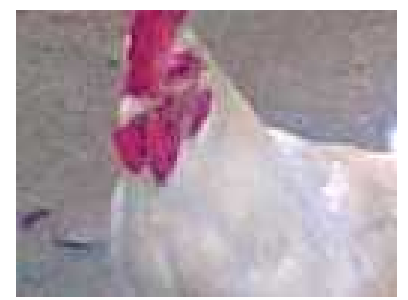

$\mathrm{a}$

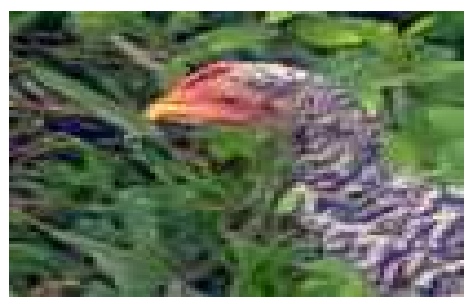

b

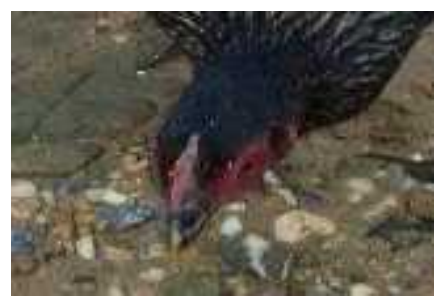

c

Gambar 7. Warna paruh ayam kampung : (a) Putih, (b) Kuning dan (c) Hitam

Umumnya warna paruh ayam kampung jantan dan betina di Kecamatan Lasalimu berwarna putih/kuning dan hitam/abu-abu. Warna paruh putih/kuning merupakan warna paruh yang dominan baik pada jantan maupun pada ternak betina. Perbedaan warna paruh pada ayam disebabkan gen yang dimilikinya. Hal ini sesuai dengan pernyataan Warwick dkk. (1995) bahwa penampilan dari suatu sifat tergantung pada gen-gen yang dimiliki ternak, tetapi keadaan lingkungan yang menunjang diperlukan untuk memberikan kesempatan penampilan suatu sifat secara penuh. Susanti dkk. (2006) melaporkan bahwa warna paruh ayam wareng yang dominan adalah warna paruh putih/kuning baik pada jantan $(91 \%)$ dan betina $(88 \%)$.

\section{Sifat Kuantitatif}

\section{Bobot Badan}

Hasil pengamatan sifat kuantitatif ayam kampung jantan dan betina yang dalam hal ini meliputi bobot badan dan ukuranukuran tubuh dapat dilihat pada Tabel 5. 
Tabel 5. Sifat Kuantitatif Ayam Kampung Berdasarkan Jenis Kelamin

\begin{tabular}{clll}
\hline \multirow{2}{*}{ No } & \multicolumn{1}{c}{ Variabel } & \multicolumn{2}{c}{ Jenis kelamin } \\
\cline { 3 - 4 } & & Jantan N =100 & Betina N =100 \\
\hline \multirow{2}{*}{1} & Bobot badan $(\mathrm{g})$ & $1753,10 \pm 139,73$ & $1216,71 \pm 130,16$ \\
& Koefisien variansi $(\%)$ & 7,97 & 10,70 \\
2 & Lingkar dada (cm) & $41,51 \pm 1,88$ & $37,47 \pm 1,04$ \\
& Koefisien variansi (\%) & 4,54 & 2,77 \\
3 & Lebar dada (cm) & $6,01 \pm 0,70$ & $5,19 \pm 0,62$ \\
& Koefisien variansi (\%) & 11,57 & 12,00 \\
4 & Panjang shank (cm) & $8,58 \pm 0,45$ & $7,06 \pm 0,44$ \\
& Koefisien variansi (\%) & 5,21 & 6,28 \\
5 & Panjang jari utama (cm) & $6,31 \pm 0,38$ & $5,32 \pm 0,38$ \\
& Koefisien variansi (\%) & 5,97 & 7,24 \\
\hline
\end{tabular}

Rata-rata bobot badan ayam kampung di Kecamatan Lasalimu pada ternak jantan adalah 1753,10 $\pm 139,73$ dengan $\mathrm{KV} 7,97 \%$ dan pada ternak betina $1216,71 \pm 130,16$ dengan KV 10,70\%. Subekti dan Arlina (2011) melaporkan rata-rata bobot badan ayam kampung di Kecamatan Sungai Pagu pada ternak jantan adalah $1,90 \mathrm{~kg} \pm 0,53$ dan pada ternak betina adalah $1,36 \mathrm{~kg} \pm 0,28$. Perbedaan hasil penelitian ini dipengaruhi oleh genetik dan lingkungan. Hal ini sesuai dengan pendapat Diwyanto (1994) bahwa setiap komponen tubuh mempunyai kecepatan pertumbuhan atau perkembangan yang berbeda-beda karena pengaruh genetik dan lingkungan.

Menurut Tantu (2007) rata-rata bobot badan ayam kampung yang dipelihara di Desa Watutela untuk ternak jantan adalah $1.975,67 \mathrm{~g}$ dengan nilai $\mathrm{KV}$ $27,20 \%$ dan pada ternak betina adalah $1.441,50 \mathrm{~g}$ dengan KV 15,39\%.

Nilai KV bobot badan ayam kampung di Kecamatan Lasalimu lebih kecil bila dibandingkan dengan hasil penlitian Tantu (2007). Hal ini menunjukan bahwa hasil penelitian ini lebih seragam bila dibandingkan dengan hasil penelitian Tantu (2007).

\section{Lingkar Dada}

Rata-rata lingkar dada ayam kampung di Kecamatan Lasalimu pada ternak jantan adalah 41,51 $\pm 1,88$ dengan
$\mathrm{KV} 4,54 \%$ dan pada ternak betina

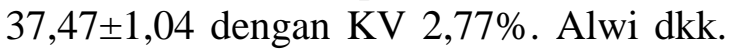
(2014) melaporkan rataan lingkar dada ayam nunukan yang dipelihara di Kecamatan Tarakan Tengah pada ternak jantan adalah $32,15 \mathrm{~cm} \pm 1,87$ dan pada ternak betina adalah $31,57 \mathrm{~cm} \pm 2,62$.

Perbedaan lingkar dada disebabkan oleh sistem pemeliharaan dan lingkungan yang berbeda. Hal ini sesuai dengan pernyataan Kusuma dan Prijono (2007) bahwa variasi ukuran tubuh ayam kampung dapat disebabkan oleh kondisi lingkungan asal bibit yang berbeda, lingkungan pemeliharaan yang berbeda.

Menurut Susanti dkk. (2006) ratarata lingkar dada ayam wareng untuk ternak jantan dewasa adalah $25,1 \mathrm{~cm} \pm 2,2$ dan KV 8,8\% sedangkan pada ternak betina didapatkan rataan $23,5 \mathrm{~cm} \pm 1,9$ dan KV $8,1 \%$. Bila dibandingkan dengan hasil penelitian ini maka lingkar dada ayam kampung lebih tinggi dibandingkan ayam wareng. Susanti dkk. (2006) menambahkan bahwa karakteristik bobot badan dan ukuran-ukuran tubuh ayam wareng lebih kecil dibandingkan dengan ayam-ayam lokal lainnya.

Nilai KV lingkar dada ayam kampung di Kecamatan Lasalimu lebih kecil bila dibandingkan dengan hasil penelitian Susanti dkk. (2006). Hal ini menunjukan bahwa hasil penelitian ini lebih seragam dari hasil penelitian Susanti dkk. (2006). 


\section{Lebar Dada}

Rata-rata lebar dada ayam kampung di Kecamatan Lasalimu pada ternak jantan adalah $6,01 \pm 0,70$ dengan $\mathrm{KV} 11,57 \%$ dan pada ternak betina $5,19 \pm 0,62$ dengan $\mathrm{KV}$ $12 \%$ Kuswardani (2012) yang melaporkan rata-rata lebar dada ayam kampung pada ternak jantan adalah $7,16 \mathrm{~cm} \pm 14,83$ dengan KV 20,71\% sedangkan pada ternak betina adalah $6,90 \mathrm{~cm} \pm 6,98$ dengan $\mathrm{KV} 10,10 \%$.

Perbedaan ukuran tubuh ayam kampung disebabkan oleh genetik, lingkungan serta pemeliharaan yang berbeda. Hal ini sesuai dengan pernyataan Kusuma dan Prijono, 2007) bahwa variasi ukuran tubuh ayam kampung dapat disebabkan oleh kondisi lingkungan asal bibit yang berbeda dan lingkungan pemeliharaan yang berbeda. Nilai KV lebar dada ayam kampung yang dipelihara di Kecamatan Lasalimu lebih kecil dari hasil penelitian Kuswardani (2012).

\section{Panjang Shank}

Rata-rata panjang shank ayam kampung jantan di Kecamatan Lasalimu adalah 8,58 $\pm 0,45$ dengan $\mathrm{KV} \mathrm{5,21 \%}$ dan ternak betina adalah 7,06 $\pm 0,44$ dengan $\mathrm{KV}$ $6,28 \%$. Budipurwanto (2001) melaporkan bahwa rata-rata panjang shank ayam kampung jantan adalah 7,75cm $\pm 1,05$ dengan KV 13,54\% sedangkan pada betina adalah 7,06cm $\pm 0,71$ dengan KV 10,09\%.

Subekti dan Arlina (2011) melaporkan rata-rata panjang shank untuk ayam kampung di Kecamatan Sungai Pagu pada ternak jantan adalah $10,36 \mathrm{~cm}$ dan pada ternak betina adalah $8,10 \mathrm{~cm}$. Perbedaan panjang shank disebabkan oleh sistem pemeliharaan dan lingkungan yang berbeda. Hal ini sesuai dengan pernyataan Kusuma dan Prijono (2007) bahwa variasi ukuran tubuh ayam kampung dapat disebabkan oleh kondisi lingkungan asal bibit yang berbeda, lingkungan pemeliharaan yang berbeda.

Nilai KV panjang shank ayam kampung dalam penelitian ini lebih kecil dibandingkan hasil penelitian Budipurwanto (2001).

\section{Panjang Jari Utama}

Rata-rata panjang jari utama ayam kampung jantan di Kecamatan Lasalimu adalah 6,31 $\pm 0,38$ dengan $\mathrm{KV} \mathrm{5,97 \%} \mathrm{dan}$ ternak betina adalah 5,32 $\pm 0,38$ dengan $\mathrm{KV}$ 7,24\%. Subekti dan Arlina (2011) melaporkan rata-rata panjang jari utama ayam kampung di Kecamatan Sungai Pagu pada ternak jantan adalah $7,32 \mathrm{~cm}$ dan pada ternak betina adalah $6,35 \mathrm{~cm}$. Perbedaan ukuran tubuh disebabkan oleh sistem pemeliharaan dan lingkungan yang berbeda-beda. Hal ini sesuai dengan pendapat (Kusuma dan Prijono, 2007) bahwa variasi ukuran tubuh ayam kampung dapat disebabkan oleh kondisi lingkungan asal bibit yang berbeda, lingkungan pemeliharaan yang berbeda dan pengaruh iklim.

Menurut Tantu (2007) rata-rata panjang jari utama untuk ayam kampung yang dipelihara di Dusun Watutela pada ternak jantan adalah $5,83 \mathrm{~cm}$ dengan $\mathrm{KV}$ $8,68 \%$ dan pada ternak betina adalah $5,10 \mathrm{~cm}$ dengan $\mathrm{KV}$ 9,95\%. Nilai KV dalam penelitian ini lebih kecil dari hasi penelitian Tantu (2007).

\section{KESIMPULAN}

Berdasarkan hasil penelitian dapat disimpulkan bahwa :

1. Berdasarkan sifat kualitatif ayam kampung di Kecamatan Lasalimu masih sangat beragam dilihat dari bentuk jengger, warna bulu, warna shank dan warna paruh.

2. Berdasarkan dari sifat kuantitatif, keragaman cukup rendah berkisar antara 2,77\%-12\%. Hal ini bermakna bahwa di Kecamatan Lasalimu telah terjadi proses seleksi pada ayam kampung yang cukup tinggi. 


\section{DAFTAR PUSTAKA}

Badan Pusat Statistik. 2015. Kabupaten Buton Dalam Angka. Badan Pusat Statistik Sulawesi Tenggara.

Budipurwanto T. 2001. Studi tentang fenotip ayam buras berdasarkan sifat kuantitatif dan kualitatif. Tesis. Fakultas Petenakan. Universitas Diponegoro.

Diwyanto K. 2003. Kebijakan Pengelolaan Sumberdaya Genetik Pertanian. Badan Litbang Pertanian, Jakarta.

Kusuma D dan N.S. Prijono. 2007. Keanekaragaman Sumber Daya Hayati Ayam Lokal Indonesia : Manfaat dan Potensi . LIPI Press. Jakarta

Kuswardani W.F.A. 2012. Studi dan ukuran bentuk tubuh ayam ketawa, ayam pelung dan ayam kampung melalui analisis komponen aku. Skripsi. Fakultas Peternakan. Institut Pertanian Bogor. Bogor

Scanes C.G, G. Brant and D.M. Ensminger. 2003. Poultry Science. $4^{\text {th }}$ Edition. Prentice Hall Publisher, Inc. Danville.

Sartika T, Sulandari S, Zein MSA, Paryanti S. 2006. Karakter fenotipe/genetic eksternal ayam lokal Indonesia. Laporan Akhir Penelitian Kompetitif Riset Karakterisasi molekuler-LIPI. $16 \mathrm{hlm}$.

Sartika T., DK. Wati, HS. Rahayu, dan S. Iskandar. 2008. Perbandingan genetik eksternal ayam wareng dan ayam kampung yang dilihat dari laju introgresi dan variabilitas genetiknya. JITV, 13(4): 279-287.

Subekti K dan F. Arlina. 2011. Karakteristik genetik eksternal ayam kampung di Kecamatan Sungai Pagu Kabupaten Solok Selatan. Jurnal Ilmiah Ilmu-Ilmu Peternakan, 14(2):74-86

Susanti T., S. Iskandar dan S. Sopiyana. 2006. Karakteristik kualitatif dan ukuran-ukuran tubuh ayam wareng. Mathius IW, Sendow I, Nurhayati,
Murdiati TB, Thalib A, Beriajaya, A Suparyanto, Prasetyo , LH Darmono, E Wina, Penyunting. Prosiding seminar ilmu dan teknologi peternakan. 5-6 September 2006. Bogor (Indonesia): Pusat penelitian dan pengembangan peternakan, Bogor. hlm. 680-686.

Tantu R.Y. 2007. Fenotipe dan genotipe ayam hutan merah (Gallus gallus) dan ayam kampung (Gallus domesticus) di Watutela dan Ngatabaru Sulawesi Tengah. Tesis. Program Pascasarjana Institut Pertanian Bogor, Bogor.

Warwick E.J., J.M. Astuti dan W. Hardjosubroto. 1995. Pemuliaan Ternak, Cet.5. Gadjah Mada University Press, Yogyakarta. 